\title{
Literasi Matematis Siswa Sekolah Menengah Atas dari Struktur Kognitif pada Konsep Limit Fungsi
}

\author{
$\operatorname{Simin}^{1}$, Ahmad Yani $\mathrm{T}^{2}$, Bistari ${ }^{3}$ \\ 1, 2, 3 Magister Pendidikan Matematika, Program Pascasarjana, Universitas Tanjungpura \\ Jl. Prof. Dr. Hadari Nawawi, Pontianak, Indonesia \\ f2181201001@ @student.untan.ac.id
}

\begin{abstract}
The problem in this study is that there are many high school students who lack mathematical literacy skills, which causes students to not understand the concept of limit functions. The purpose of this study was to examine the mathematical literacy of high school students from the cognitive structure to the concept of limit function. The research method used is descriptive research method with a qualitative approach. Respondents in this study were high school students who had studied the concept of limit function, totaling 36 students. These respondents were then divided into three groups of students based on their cognitive structure. The criteria for selecting respondents in this study were based on students' mathematical literacy abilities. The results showed that the cognitive structure of high school students on the concept of function limits can be developed through mathematical literacy with the stages of identification, modeling, procedural, and confirmation. Students with low cognitive structure can only reach level 2 of mathematical literacy on the concept of function limits. Students with moderate and high cognitive structure both can only reach level 3 mathematical literacy on the concept of function limits. It is important to continue the development of mathematical literacy, especially in terms of content and context.
\end{abstract}

Keywords: Functional limits, mathematical literacy, development, students, cognitive structure.

\begin{abstract}
Abstrak
Masalah dalam penelitian ini adalah banyaknya siswa sekolah menengah atas yang kurang memiliki kemampuan literasi matematis yang menyebabkan tidak pahamnya siswa dalam memahami konsep limit fungsi. Tujuan penelitian ini adalah untuk mengkaji literasi matematis siswa sekolah menengah atas dari struktur kognitif pada konsep limit fungsi. Metode penelitian yang digunakan adalah metode penelitian deskriptif dengan pendekatan kualitatif. Responden dalam penelitian ini adalah siswa-siswa sekolah menengah atas yang telah mempelajari konsep limit fungsi yang berjumlah 36 siswa. Responden ini kemudian dibagi menjadi tiga kelompok siswa berdasarkan struktur kognitifnya. Kriteria pemilihan responden pada penelitian ini berdasarkan kemampuan literasi matematis siswa. Hasil penelitian menunjukan bahwa struktur kognitif siswa sekolah menengah atas pada konsep limit fungsi dapat dikembangkan melalui literasi matematis dengan tahapan identifikasi, pemodelan, prosedural, dan konfirmasi. Siswa dengan struktur kognitif rendah hanya bisa mencapai level 2 literasi matematis pada konsep limit fungsi. Siswa dengan struktur kognitif sedang dan tinggi sama-sama hanya bisa mencapai level 3 literasi matematis pada konsep limit fungsi. Pengembangan literasi matematis ini penting untuk dilanjutkan, terutama pada aspek konten dan konteks.
\end{abstract}

Kata kunci: Limit fungsi, literasi matematis, pengembangan, siswa, struktur kognitif.

Copyright (c) 2021 Simin, Ahmad Yani T, Bistari

$\square$ Corresponding author: Simin

Email Address: f2181201001@ @student.untan.ac.id (Jl. Prof. Dr. Hadari Nawawi, Pontianak, Indonesia)

Received 11 September 2021, Accepted 14 December 2021, Published 27 December 2021

\section{PENDAHULUAN}

Pada hakekatnya, pendidikan matematika mempunyai dua arah pengembangan, yaitu memenuhi kebutuhan saat ini dan memenuhi kebutuhan masa depan (Asmara, A. et al., 2017). Pengembangan untuk saat sekarang diarahkan pada pengembangan keterampilan matematika dan terapannya. Pengembangan generasi mendatang memiliki pengertian yang global diantaranya untuk penalaran logis, kritis serta berpikir terbuka (Fathani, A., 2016), maka literasi matematis dari struktur 
kognitif siswa perlu dikembangkan.

Literasi matematis adalah kemampuan siswa dalam merumuskan juga menafsirkan melalui penalaran matematis dengan menggunakan konsep-konsep matematika, fakta, dan juga fungsi matematika dalam menggambarkan dan memprediksi suatu fenomena ((Pasandaran, R., 2018); (OECD, 2003)). Gambaran kinerja PISA mengenai literasi matematis diukur dalam tiga konstruk sebagai berikut: konten, konteks, dan kognitif ((OECD, 2003); (Jablonka, 2003)). Aspek kognitif terdiri dari tiga kelompok sebagai berikut: Kelompok reproduksi, kelompok koneksi, dan kelompok refleksi. Pada kegiatan reproduksi, siswa diminta menunjukan bahwa siswa mengenali fakta dan juga dapat menggunakan skills teknis. Pada kelompok koneksi, siswa diminta untuk menunjukan hubungan antara gagasan dalam matematika untuk menyelesaikan permasalahan. Pada kegiatan refleksi, siswa diminta mengungkapkan ide yang melatarbelakangi masalah. Refleksi ini merupakan pencapaian tertinggi dalam penilaian PISA (OECD, 2003). Siswa menggunakan pemikirannya untuk memecahkan masalah. Siswa menganalisis situasi yang dihadapinya dan membuat strategi penyelesaiannya (Kaiser \& Willander, 2005). Pengertian literasi matematis dan bagaimana literasi matematis tersebut diukur menunjukan begitu pentingnya literasi matematis siswa untuk dikembangkan. Salah satu konsep yang harus dikembangkan pada literasi matematis ini adalah konsep limit fungsi.

Konsep limit fungsi adalah materi matematika Sekolah Menengah Atas (SMA) kelas XI. Materi konsep limit sangat penting dikuasai siswa karena konsep ini prasyarat turunan fungsi. Kesulitan siswa pada konsep limit fungsi membuat hasil belajar tidak maksimal. Kesulitan siswa ini disinyalir karena kurangnya literasi matematis yang dimiliki siswa, dimana literasi matematis ini erat kaitannya dengan struktur kognitif yang dimiliki siswa. Siswa seringkali mendapatkan nilai yang tidak memuaskan atau kurang dari nilai Kriteria Ketuntasan Minimal (KKM). Tidak tercapainya KKM ini bukan karena siswa tidak pandai, namun siswa cenderung tidak mengerti pertanyaan yang diberikan, dan hal ini sangat berkaitan dengan literasi matematis dan struktur kognitif yang dimiliki siswa.

Penelitian-penelitian sebelumnya yang membahas mengenai literasi matematis dan struktur kognitif tidak menunjukan pengembangan literasi matematis siswa SMA dari struktur kognitif siswa, apalagi secara khusus pada konsep limit fungsi. Penelitian (Ulya, S. \& Wardono, 2019) menunjukan bahwa literasi matematis yang dimiliki siswa perlu adanya pengembangan lebih lanjut kaitannya dengan capaian yang diinginkan dalam literasi matematis. Pencapaiannya harus diketahui faktor apa yang dapat mempengaruhi capaian tersebut. Begitupun penelitian (Kusmaryono et al., 2020) menjelaskan bahwa struktur berpikir penalaran logis perlu dikembangkan dan scaffolding bisa menjadi strategi yang berguna untuk membantu siswa melewati Zone of Proximal Development (ZPD) yang berbeda. Kebaruan penelitian ini adalah pengembangan literasi matematis siswa SMA dari konsep limit fungsi yang dianalisis dari struktur kognitifnya, dimana pengembangan ini belum pernah dilakukan oleh ahli-ahli sebelumnya.

Berdasarkan deskripsi sebelumnya, maka peneliti membatasi literasi matematis pada aspek 
kognitif saja, khususnya pada konsep limit fungsi. Tujuan pengembangan literasi matematis pada penelitian ini adalah kemampuan siswa menggunakan konsep-konsep limit fungsi melalui prosedur matematis tertentu. Penyelesaian masalah literasi matematis ini dikelompokan beberapa tahapan sebagai berikut: tahap mengidentifikasi, pemodelan, prosedural, dan konfirmasi. Pengembangan literasi matematis siswa SMA dari struktur kognitif pada konsep limit fungsi ini harapannya bisa menjawab masalah yang selama ini dihadapi siswa (Umbara \& Suryadi, 2019). Diharapkan penelitian ini bisa memberikan manfaat serta kebaruan dalam hal pengembangan literasi matematis yang khusus fokus kepada aspek kognitif dan konsep limit fungsi.

\section{METODE}

Metode yang digunakan dalam penelitian ini adalah metode deskriptif dengan pendekatan kualitatif. Pendekatan ini bisa peneliti katakan sebagai sebuah cara meneliti berlandaskan filsafat post positivisme, dimana pendekatan ini meneliti kondisi obyek secara alami dan digunakan untuk data yang mendalam (Asmara, A. et al., 2017). Penelitian ini dilakukan di SMAN 2 Kabupaten Sanggau di kelas XI pada bulan Maret 2021. Populasi pada penelitian ini adalah seluruh siswa kelas XI yang berjumlah 180 siswa. Responden yang digunakan berjumlah 36 siswa. Responden ini kemudian dikelompokan berdasarkan tingkat kemampuan kognitifnya. Kriteria pemilihan responden pada penelitian ini berdasarkan kemampuan literasi matematis siswa. Pengelompokan dilakukan berdasarkan data ulangan harian yang didapatkan. Pengkategorian kelompok siswa ini dilakukan berdasarkan nilai KKM berikut:

Tabel 1. Kriteria Nilai Kognitif Siswa
\begin{tabular}{|c|c|c|}
\hline No. & Nilai & Kategori \\
\hline 1 & $>70$ & Tinggi \\
\hline 2 & $=70$ & Sedang \\
\hline 3 & $<70$ & Rendah \\
\hline
\end{tabular}

Analisis ketercapaian indikator literasi matematis siswa dibuktikan melalui tes. Lembar observasi juga wawancara digunakan juga untuk mengukur ketercapaian literasi matematis siswa yang tidak teramati saat tes. Level literasi matematis siswa mengacu pada Tabel berikut:

Tabel 2. Tingkat Literasi Matematis

\begin{tabular}{|c|l|}
\hline Level/Tingkatan & \multicolumn{1}{c|}{ Kegiatan } \\
\hline 1 & $\begin{array}{l}\text { Siswa dapat menjawab pertanyaan serta dapat memberikan informasi relevan } \\
\text { dengan pernyataan yang jelas. }\end{array}$ \\
\hline 2 & Siswa mengenali situasi yang memerlukan kesimpulan langsung. \\
\hline 3 & Siswa melaksanakan prosedur dengan jelas. \\
\hline 4 & Siswa bekerja efektif dan melibatkan pembatasan dalam membuat asumsi. \\
\hline 5 & Siswa bekerja menggunakan model. \\
\hline 6 & Siswa dapat pengkonsep dan memakai informasi berdasarkan pemodelan. \\
\hline
\end{tabular}

(Sumber: (OECD, 2003); (Asmara, A. et al., 2017)).

Langkah selanjutnya menentukan tingkat literasi matematis. Langkah-langkah penelitian dapat 
dilihat pada skema berikut:

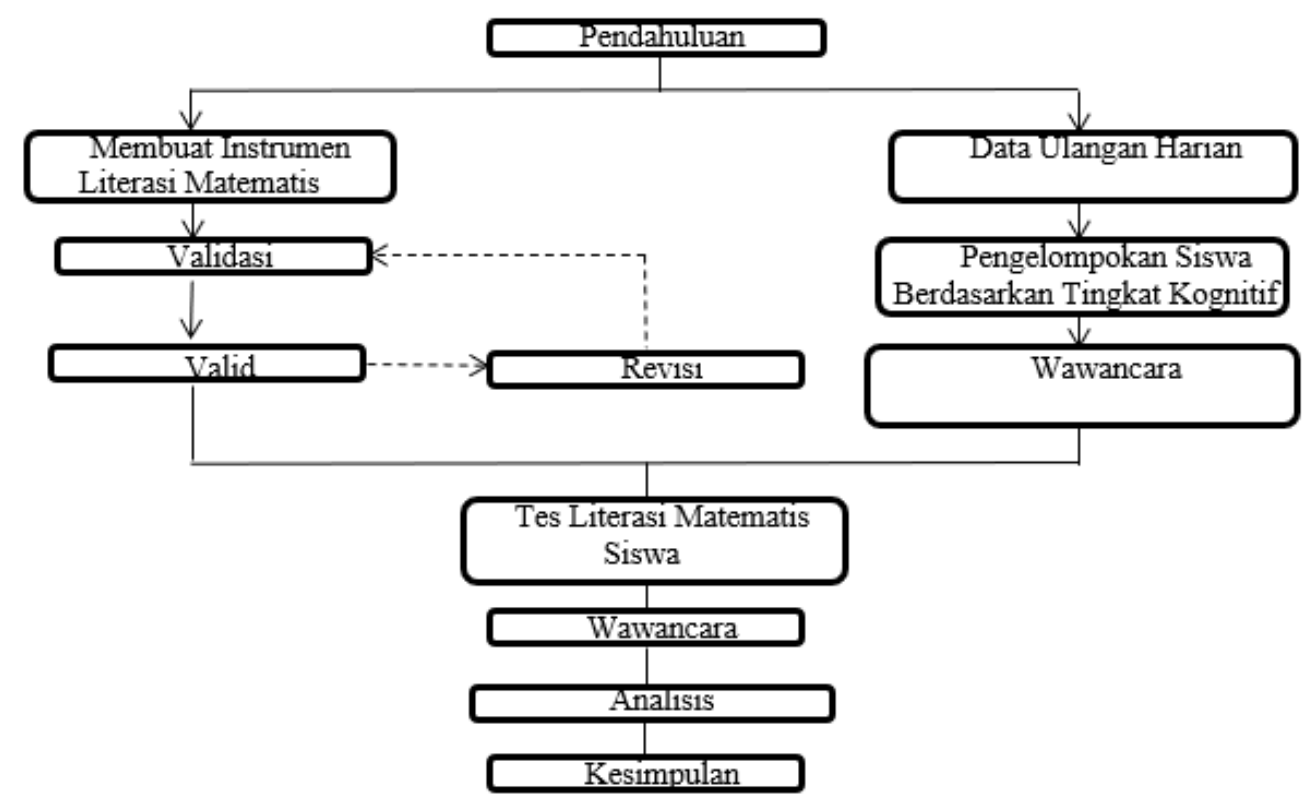

Gambar 1. Skema Langkah-langkah Penelitian

\section{HASIL DAN DISKUSI}

Pengelompokan dilakukan berdasarkan data ulangan harian yang didapatkan. Pengkategorian kelompok siswa dilakukan berdasarkan nilai KKM. Data pengelompokan siswa direkapitulasi pada Tabel berikut:

Tabel 3. Pengelompokan Siswa berdasarkan Ulangan Harian Matematika

\begin{tabular}{|c|c|c|}
\hline Kode Siswa & Nilai & Kategori \\
\hline S1 & 65 & Rendah \\
\hline S2 & 60 & Rendah \\
\hline S3 & 68 & Rendah \\
\hline S4 & 68 & Rendah \\
\hline S5 & 65 & Rendah \\
\hline S6 & 60 & Rendah \\
\hline S7 & 60 & Rendah \\
\hline S8 & 60 & Rendah \\
\hline S9 & 65 & Rendah \\
\hline S10 & 68 & Rendah \\
\hline S11 & 68 & Rendah \\
\hline S12 & 65 & Rendah \\
\hline S13 & 70 & Sedang \\
\hline S14 & 70 & Sedang \\
\hline S15 & 70 & Sedang \\
\hline S16 & 70 & Sedang \\
\hline S17 & 70 & Sedang \\
\hline S18 & 70 & Sedang \\
\hline S19 & 70 & Sedang \\
\hline S20 & 70 & Sedang \\
\hline S21 & 70 & Sedang \\
\hline S22 & 70 & Sedang \\
\hline
\end{tabular}




\begin{tabular}{|c|c|c|}
\hline Kode Siswa & Nilai & Kategori \\
\hline S23 & 70 & Sedang \\
\hline S24 & 70 & Sedang \\
\hline S25 & 72 & Tinggi \\
\hline S26 & 75 & Tinggi \\
\hline S27 & 80 & Tinggi \\
\hline S28 & 75 & Tinggi \\
\hline S29 & 80 & Tinggi \\
\hline S30 & 85 & Tinggi \\
\hline S31 & 90 & Tinggi \\
\hline S32 & 75 & Tinggi \\
\hline S33 & 75 & Tinggi \\
\hline S34 & 78 & Tinggi \\
\hline S35 & 72 & Tinggi \\
\hline S36 & 75 & Tinggi \\
\hline
\end{tabular}

Pada tahap awal penelitian ini, berdasarkan data diatas menunjukan bahwa kelompok siswa tersebar dengan jumlah dan komposisi yang sama dan berimbang, dimana kelompok siswa berada pada kategori rendah, sedang, dan tinggi sama-sama berjumlah 12 siswa. Hal ini sejalan dengan penelitian (Amalia et al., 2021) yang mendeskripsikan bahwa kemampuan siswa pada tahap awal penelitian harus menunjukan kemampuan siswa yang heterogen. Tahap berikutnya adalah tes kemampuan literasi matematis siswa. Tes ini berjumlah 6 buah soal uraian tentang konsep limit fungsi. Rekapitulasi data hasil tes literasi matematis pada konsep limit fungsi ditampilkan sebagai berikut:

Tabel 4. Rekapitulasi Tes Literasi Matematis Konsep Limit Fungsi

\begin{tabular}{|c|c|c|}
\hline Kode Siswa & Nilai & Kategori \\
\hline S1 & 68 & Rendah \\
\hline S2 & 62 & Rendah \\
\hline S3 & 68 & Rendah \\
\hline S4 5 & 68 & Rendah \\
\hline S6 & 65 & Rendah \\
\hline S7 & 62 & Rendah \\
\hline S8 & 62 & Rendah \\
\hline S9 & 65 & Rendah \\
\hline S10 & 68 & Rendah \\
\hline S11 & 68 & Rendah \\
\hline S12 & 65 & Rendah \\
\hline S13 & 70 & Sedang \\
\hline S14 & 70 & Sedang \\
\hline S15 & 70 & Sedang \\
\hline S16 & 70 & Sedang \\
\hline S17 & 70 & Sedang \\
\hline S18 & 70 & Sedang \\
\hline S19 & 70 & Sedang \\
\hline S20 & 70 & Sedang \\
\hline S21 & 70 & Sedang \\
\hline S22 & 70 & Sedang \\
\hline
\end{tabular}




\begin{tabular}{|c|c|c|}
\hline Kode Siswa & Nilai & Kategori \\
\hline S23 & 70 & Sedang \\
\hline S24 & 70 & Sedang \\
\hline S25 & 75 & Tinggi \\
\hline S26 & 80 & Tinggi \\
\hline S27 & 80 & Tinggi \\
\hline S28 & 75 & Tinggi \\
\hline S29 & 80 & Tinggi \\
\hline S30 & 85 & Tinggi \\
\hline S31 & 90 & Tinggi \\
\hline S32 & 80 & Tinggi \\
\hline S33 & 75 & Tinggi \\
\hline S34 & 78 & Tinggi \\
\hline S35 & 75 & Tinggi \\
\hline S36 & 75 & Tinggi \\
\hline
\end{tabular}

Pada tahap tes literasi matematis, secara umum siswa mengalami peningkatan nilai apabila dibandingkan dengan data hasil ulangan harian yang didapatkan dari guru. Tidak semua siswa nilai tes literasi matematisnya meningkat setelah melakukan pembelajaran literasi matematis pada konsep limit fungsi. Peningkatan nilai tes literasi matematis ini mirip dengan yang dilakukan oleh (Sukma \& Supriyono, 2019) dimana kedua ahli tersebut mengemukakan model discovery learning meningkatkan hasil belajar literasi matematis pada konsep limit.

Analisis berikutnya adalah analisis siswa berdasarkan kelompoknya. Jumlah sampel setiap kelompok yang berjumlah masing-masing 12 siswa kemudian diambil 3 siswa yang mewakili siswa masing-masing kelompoknya untuk diwawancara mengenai tes dan pembelajaran yang telah dilakukan. Analisis dan diskusinya dideskripsikan sebagai berikut:

\section{Siswa dengan Struktur Kognitif Rendah}

Tabel 5. Data Nilai Awal dan Nilai Tes Literasi Matematis Siswa Kelompok Rendah

\begin{tabular}{|c|c|c|c|}
\hline Kode Siswa & Nilai Awal & Nilai Tes Literasi Matematis & Kategori \\
\hline S1 & 65 & 68 & Rendah \\
\hline S2 & 60 & 62 & Rendah \\
\hline S3 & 68 & 68 & Rendah \\
\hline S4 & 68 & 68 & Rendah \\
\hline S5 & 65 & 65 & Rendah \\
\hline S6 & 60 & 62 & Rendah \\
\hline S7 & 60 & 62 & Rendah \\
\hline S8 & 60 & 65 & Rendah \\
\hline S9 & 65 & 65 & Rendah \\
\hline S10 & 68 & 68 & Rendah \\
\hline S11 & 68 & 68 & Rendah \\
\hline S12 & 65 & 65 & Rendah \\
\hline
\end{tabular}

Siswa dengan struktur kognitif rendah (SR) bisa menyelesaikan semua soal, namun jawabannya tidak semua benar. Kelompok SR ini hanya bisa menjawab soal literasi matematis tingkat 1. Kelompok SR bisa menjawab dengan informasi relevan dari pertanyaan yang diberikan. Penelitian 
(Oktaviyanthi et al., 2018) mendeskripsikan hasil jawaban siswa memerlukan strategi pada tahap persiapan pembuktian juga pada tahap pembuktian, dan hal ini merupakan sesuatu yang sulit dilakukan siswa pada umumnya.

Pada soal literasi matematis tingkat 2, kelompok SR bisa menafsirkan yang memerlukan kesimpulan langsung. Pada level 2 kelompok SR bisa memilah dan memilih informasi secara tepat. Soal tingkat 3 dan selanjutnya, kelompok SR rata-rata menjawab salah. Hasil wawancara didapatkan meskipun dikerjakan, tetapi rata-rata kelompok SR merasa tidak bisa. Mereka menjawab apa yang mereka pikirkan dan berusaha mengaitkan dengan soal yang sedang dikerjakan. Kelompok SR tidak bisa memenuhi kompetensi literasi matematis diatas level 3 .

Kelompok SR hanya memenuhi sampai kompetensi litetasi matematis level 2 saja. Siswa-siswa dengan struktur kognitif rendah yang hanya memenuhi level 2 dalam literasi matematis ini perlu didampingi agar bisa tetap hidup di zaman yang sudah modern. Penelitian (Kusumah, Y., 2018) yang mengungkapkan individu-individu harus mempunyai literasi matematis agar tidak tergerus oleh zaman yang semakin canggih dan tidak menjadi penonton di negeri sendiri.

\section{Siswa dengan Struktur Kognitif Sedang}

Tabel 6. Data Nilai Awal dan Nilai Tes Literasi Matematis Siswa Kelompok Sedang

\begin{tabular}{|c|c|c|c|}
\hline Kode Siswa & Nilai Awal & Nilai Tes Literasi Matematis & Kategori \\
\hline S13 & 70 & 70 & Sedang \\
\hline S14 & 70 & 70 & Sedang \\
\hline S15 & 70 & 70 & Sedang \\
\hline S16 & 70 & 70 & Sedang \\
\hline S17 & 70 & 70 & Sedang \\
\hline S18 & 70 & 70 & Sedang \\
\hline S19 & 70 & 70 & Sedang \\
\hline S20 & 70 & 70 & Sedang \\
\hline S21 & 70 & 70 & Sedang \\
\hline S22 & 70 & 70 & Sedang \\
\hline S23 & 70 & 70 & Sedang \\
\hline S24 & 70 & 70 & Sedang \\
\hline
\end{tabular}

Berdasarkan hasil analisis, kelompok siswa dengan struktur kognitif sedang bisa mengerjakan soal, tetapi hasilnya tidak semua benar. Soal dengan tingkat 1 , kelompok siswa dengan struktur kognitif sedang dapat menjawab benar. Siswa nampaknya sudah terbiasa dengan soal-soal literasi matematis tingkat 1 . Soal level 2 juga bisa dijawab dengan benar seperti membuat kesimpulan langsung. Untuk level 3, kelompok siswa dengan struktur kognitif sedang tidak bisa semuanya menjawab dengan benar. Kebanyakan siswa dalam kelompok struktur kognitif sedang ragu dengan jawaban yang diberikan. Penelitian (Rahayu, D. et al., 2020) mendeskripsikan bahwa literasi matematis siswa Indonesia termasuk rendah. Salah satu faktornya adalah faktor pribadi siswa yang berkaitan dengan cara menerima dan mengolah informasi yang ada.

Untuk level 3 ini, kelompok siswa dengan struktur kognitif sedang hanya bisa melakukan tahapan dengan benar serta sistematis. Untuk soal level 4, 5, dan 6, kelompok siswa struktur kognitif 
sedang menjawab dengan tidak tepat. Berdasarkan wawancara, kebanyakan siswa pada kelompok struktur kognitif sedang mengungkapkan jawaban ditulis ragu-ragu. Saat ditanya, rata-rata kelompok siswa dengan struktur kognitif sedang menjawab sudah lupa karena wawancara dilakukan agak lama setelah tes literasi matematis dilaksanakan. Kelompok siswa dengan struktur kognitif sedang ada pada tingkat 3 kemampuan literasi matematis.

\section{Siswa dengan Struktur Kognitif Tinggi}

Tabel 7. Data Nilai Awal dan Nilai Tes Literasi Matematis Siswa Kelompok Tinggi

\begin{tabular}{|c|c|c|c|}
\hline Kode Siswa & Nilai Awal & Nilai Tes Literasi Matematis & Kategori \\
\hline S25 & 72 & 75 & Tinggi \\
\hline S26 & 75 & 80 & Tinggi \\
\hline S27 & 80 & 80 & Tinggi \\
\hline S28 & 75 & 75 & Tinggi \\
\hline S29 & 80 & 80 & Tinggi \\
\hline S30 & 85 & 85 & Tinggi \\
\hline S31 & 90 & 90 & Tinggi \\
\hline S32 & 75 & 80 & Tinggi \\
\hline S33 & 75 & 75 & Tinggi \\
\hline S34 & 78 & 78 & Tinggi \\
\hline S35 & 72 & 75 & Tinggi \\
\hline S36 & 75 & 75 & Tinggi \\
\hline
\end{tabular}

Kelompok siswa dengan struktur kognitif tinggi (ST) hanya bisa menjawab benar soal tingkat 1 sampai 3. Soal tingkat 4 keatas, kelompok siswa dengan struktur kognitf tinggi tidak bisa menjawab. Saat diwawancara, kelompok SR menjelaskan rata-rata merasa tidak mengetahui jawabannya. Kelompok ST sudah terbiasa untuk menjawab pertanyaan serta mampu memberikan alasan yang tepat. Kelompok ST terbiasa melakukan langkah-langkah yang memerlukan keputusan secara sistematis. Kelompok siswa dengan struktur kognitif tinggi ada pada tingkat 3. Hal ini tidak mengherankan karena sejalan dengan penelitian (Dazrullisa \& Mahdi, T., 2020) yang mendeskripsikan bahwa kemampuan siswa pada kelompok sedang dan tinggi secara umum tidak berbeda secara signifikan. Berdasarkan hasil penelitian yang dideskripsikan sebelumnya, dapat dikatakan kelompok siswa dengan struktur kognitif sedang dan siswa dengan struktur kognitif tinggi ada di level 3 kemampuan literasi matematis. Kelompok SR ada pada level 2.

\section{KESIMPULAN}

Struktur kognitif siswa SMA pada konsep limit fungsi dapat dikembangkan melalui literasi matematis. Literasi matematis hanya sampai dengan level 3. Siswa tidak terbiasa dengan soal-soal pemikiran logis serta solusi yang aplikatif. Siswa biasa menjawab secara tahap dan langkah-langkah yang nyata. Perlu strategi cerdas untuk memberi kebiasaan siswa menjawab soal-soal penalaran logis. Literasi matematis perlu dikembangkan lebih lanjut dalam aspek konten dan juga aspek konteks, sehingga literasi matematis yang dimiliki siswa akan lebih komprehensif. 


\section{UCAPAN TERIMA KASIH}

Peneliti berterimakasih kepada Dosen-dosen Prodi Magister Pendidikan Matematika Universitas Tanjungpura yang memberikan support dalam penelitian ini. Peneliti mengucapkan terima kasih juga pada pengelola jurnal Cendekia: Jurnal Pendidikan Matematika dan para reviewer yang telah memberikan komentar dan arahan atas artikel ini.

\section{REFERENSI}

Amalia, A., Rusdi, \& Kamid. (2021). Pengembangan Soal Matematika Bermuatan HOTS Setara PISA Berkonteks Pancasila. Jurnal Cendekia:Jurnal Pendidikan Matematika, 05(01), 1-19.

Asmara, A., S., Waluya, S., B., \& Rochmad. (2017). Analisis Kemampuan Literasi Matematika Siswa Kelas X Berdasarkan Kemampuan Matematika. Jurnal Scholaria, 7(2), 135-142.

Dazrullisa, \& Mahdi, T., C. (2020). Pengaruh Penggunaan Model Pembelajaran Discovery Learning Terhadap Pemahaman Konsep Matematis Siswa Dengan Menggunakan Geometric Sketcpad. Jurnal Numeracy, 7(1), 1-19.

Fathani, A., H. (2016). Pengembangan Literasi Matematika Sekolah Dalam Perspektif Multiple Intelligences. Jurnal EduSains, 4(2), 136-150.

Jablonka, E. (2003). Mathematical Literacy. In Second International Handbook of Mathematics Education (Issue 2, pp. 75-102).

Kaiser, G., \& Willander, T. (2005). Development of mathematical literacy: Results of an empirical study. Teaching Mathematics and Its Applications Journal, 24(2), 48-60. https://doi.org/10.1093/teamat/hri016

Kusmaryono, I., Ubaidah, N., \& Basir, M., A. (2020). THE ROLE OF SCAFFOLDING IN THE DECONSTRUCTING OF THINKING STRUCTURE: A CASE STUDY OF PSEUDOTHINKING PROCESS. Infinity Journal of Mathematics Education, 9(2), 247-262.

Kusumah, Y., S. (2018). Literasi Matematis Sebagai Ketrampilan Minimal Dalam Menghadapi Tantangan Di Abad 21. Optimalisasi Literasi Matematis Dalam Sudut Pandang Saintifik, 1-8.

OECD. (2003). Mathematical Literacy. In The PISA 2003 Assessment Framework - Mathematics, Reading, Science and Problem Solving Knowledge and Skills (pp. 24-102).

Oktaviyanthi, R., Herman, T., \& Dahlan, J., A. (2018). HOW DOES PRE-SERVICE MATHEMATICS TEACHER PROVE THE LIMIT OF A FUNCTION BY FORMAL DEFINITION? Journal on Mathematics Education, 9(2), 195-212.

Pasandaran, R., F. (2018). Taksonomi SOLO (Structure of Observed Learning Outcomes) sebagai Assessment Autentik untuk Membangun Kemampuan Literasi Mahasiswa dalam Mengidentifikasi Grafik Fungsi Trigonometri. Jurnal Penelitian Matematika Dan Pendidikan Matematika, 1(1), 88-164.

Rahayu, D., U., Mulyono, \& Cahyono, A., N. (2020). Kemampuan Literasi Matematika Ditinjau Dari Gaya Kognitif Siswa Pada Model PBL Berbantuan LMS. SEMINAR NASIONAL 
Literasi Matematis Siswa Sekolah Menengah Atas dari Struktur Kognitif pada Konsep Limit Fungsi, Simin, Ahmad Yani

PASCASARJANA 2020, 1, 715-720.

Sukma, Y., \& Supriyono, A. (2019). Peningkatan Hasil Belajar Siswa Materi Limit Fungsi Aljabar Menggunakan Discovery Learning Di SMAN 10 PALEMBANG. Lentera Sriwijaya: Jurnal Ilmiah Pendidikan Matematika, 1(2), 13-24.

Ulya, S., F., \& Wardono. (2019). Upaya Pengembangan untuk Capaian Literasi Matematika. PRISMA, Prosiding Seminar Nasional Matematika, 2, 589-596.

Umbara, U., \& Suryadi, D. (2019). Re-Interpretation of Mathematical Literacy Based on the Teacher ' s Perspective. International Journal of Instruction, 12(4), 789-806. 